Dorota Huzarska-Ryzenko

Medical University of Bialystok

e-mail: dorotahuzarska@poczta.onet.pl

ORCID: 0000-0002-6190-6573

Joanna Huzarska

University of Bialystok

e-mail: huzarska@uwb.edu.pl

ORCID: 0000-0001-7418-4701

\title{
Bartosz Pędziński
}

Medical University of Bialystok

e-mail: bartosz@pedzinski.pl

ORCID: 0000-0002-7644-1764

\section{HEALTH SECURITY IN A DEMOCRATIC STATE: CHILD VACCINATION - LEGAL OBLIGATION VERSUS THE RIGHT TO EXPRESS CONSENT FOR A MEDICAL INTERVENTION}

\begin{abstract}
One of the major objectives in a democratic state is ensuring health security of the citizens including combating epidemic diseases. The subject matter of this article is the presentation and analysis of legal regulations regarding preventive vaccination in Poland, in particular the aspect of imposing a legal obligation and restricting parents' right to express consent for medical intervention. The reflections made herein are aimed at finding an answer to the question whether the adopted legal solutions are admissible in a democratic state with regard to ensuring health security. The purpose of the analysis is also to assess whether the abovementioned legal regulations have been formulated in a clear way and do not raise interpretation doubts and, consequently, whether they are comprehensible to the parents obliged to comply with them.

As it follows from analysis of the legal provisions, parents must not refuse to subject a child to obligatory preventive vaccination and their consent is not required by law, both as regards the medical qualifying examination to exclude contraindications to performing vaccination and the vaccination itself. It is a legal obligation, from which exemption is only possible on grounds of certain medical conditions that would render vaccination inadvisable.

The legal provisions that concern obligatory preventive vaccination in Poland, including in particular those referring to its enforceability, have not been formulated in a way that is sufficiently comprehensible to parents who are under the obligation of complying with them, irrespective of the fact that the language of the provisions of law should be clear and raise no interpretative doubts.
\end{abstract}


In a democratic state the protection of public health against epidemic hazards justifies the implementation of legal solutions that restrict an individual's freedom of self-determination, thus limiting the right of patients or their statutory representatives to grant or refuse consent for a medical intervention in the form of preventive vaccination - the purpose of this legal solution being to prioritize the safeguarding of state health security.

It is vitally important to engage in a social dialogue with the purpose of convincing the public of the need for vaccination, its significance and its implementation for the better good.

Keywords: preventive vaccination, parents' consent, health security.

\section{Introduction}

One of the major objectives in a democratic state is to ensure the health security of its citizens and that of persons staying on its territory. Combating epidemic diseases, including contagious diseases and infections in humans, is one of the strategic goals connected with state health policy. In this regard, Poland has for many years been implementing a mass preventive vaccination plan. It is frequently modified to keep pace with current medical knowledge and takes into consideration the epidemiologic situation in Europe as a whole.

The subject matter of this article is the presentation and analysis of legal regulations regarding preventive vaccination in Poland, in particular the aspect of imposing a legal obligation and restricting parents' right to express consent for medical intervention. The reflections made herein are aimed at demonstrating that in a democratic state obligatory preventive vaccination does not constitute an excessive limitation of constitutional rights and freedoms of the citizens. Indeed, it is necessary to realize public interest - ensuring health security.

The purpose of the analysis is also to assess whether the abovementioned legal regulations have been formulated clearly, do not raise interpretative doubts and are comprehensible to the parents obliged to comply with them.

\section{Preventive vaccination - public debate}

Introducing obligatory preventive vaccination is based on the provisions of the Constitution of the Republic of Poland (hereinafter, the Constitution), in particular on Art. 31 Par. 3. This provision sets certain limits on the exercise of constitutional freedoms and rights when it becomes necessary in a democratic state to serve the better good. Among others, this applies to the protection of public health and the protection of other per- 
sons' rights. The obligation of compulsory vaccination concerns the prevention and spread of contagious diseases among Poland's population as well as among persons staying on its territory. Responsibility for the prevention of epidemic diseases is a constitutional obligation that falls on public authorities, Art. 68 Par. 4 of the Constitution.

In the broad sense, preventive vaccination has been generally accepted as an effective way to obviate the occurrence of contagious diseases. However, for some time now anti-vaccine associations and movements have progressively intensified their activity, which has resulted in a growing tendency among parents not to have their children vaccinated. As justification, parents who chose to follow this path invariably point to the right to decide on the method of treatment, fear of post-vaccine complications and concerns about their child's future health.

In consequence, the issue of obligatory preventive vaccination attracted with increasing frequency the attention of the media and likewise it became the subject of political debate, as illustrated by the parliamentary interpellation addressed to the Minister of Health on the lifting of sanctions resulting from the statutory vaccination obligation and the introduction of voluntary vaccination (Sejm RP, Interpelacja nr. 7940, 21.11.2016). In 2018, Parliament was presented with a civic bill to lift the obligation of preventive vaccination which had been signed by approximately 120,000 people (exhibit nr. 2796) (Sejm RP, Interpelacja nr. 7940).

The bill itself was rejected in the second reading but the large scale of social concern about vaccination and the growing number of non-vaccinated children in Poland, still stand as undeniable facts. As a result, there has been a decrease in vaccination coverage levels of some diseases to below the safety threshold, which in essence means that Polish society begins to be exposed to the risk of a resurgence of epidemic diseases that long ago were thought to have been eradicated. By way of example, according to statistics revealed by the National Institute of Public Health - National Institute of Hygiene, in 2018 the recorded status level of vaccinations against measles was below $93 \%$, whereas, according to the recommendations of the World Health Organization (WHO), to sustain group immunity the status of vaccination should be at least $95 \%$. Only at this level can conditions be maintained in which non-vaccinated persons are also protected (Dziennik.pl, Likwidacja obowiazku szczepień. Burzliwa debata w Sejmie - Removal of vaccination obligations. A turbulent debate in the Sejm).

As will be discussed in more detail further on in this paper, the legal regulations applicable in Poland create circumstances for implementing a preventive vaccination plan, and the consent of the person subject to vac- 
cination is not required in order to conduct it. However, in a democratic state an obligation of this nature should only be introduced in parallel with other activities aimed at alleviating social concerns. Therefore, undertaking a nationwide public awareness programme is of vital importance. The population at large is entitled to know and must be suitably educated on the significance and benefits of vaccination, both for the health of the vaccinated individual and for society as a whole.

Today, in the opinion of many parents whose children are to undergo preventive vaccination, this obligation is perceived in the context of the right to autonomously determine their own and their children's destiny, as well as the way in which their health is taken care of. In this regard, it would seem that medical professionals along with others involved in implementing the preventive vaccination plan, are not effectively communicating its dual function, that is not only the protection of an individual against illnesses but also the protection of society against epidemics. Such opinion was explicitly expressed in the Parliament during the debate on the aforementioned bill by the National Consultant for Public Health, Jarosław Pinkas, who also emphasized that "the fact that we are now discussing the bill and have doubts as for the vaccination plan and vaccination safety is the consequence of a big mistake, a mistake in communication with the society, mainly on the part of medical circles but also on the part of all politicians involved in [public] health" (Dziennik.pl, Likwidacja obowiazku szczepień. Burzliwa debata w Sejmie).

An essential element of such perception of the issue of vaccination within society is the fact that for most people the problem of mass epidemics seems distant. Their appreciation of the scale of risk involved is detached, it is not built on personal experience nor through communication with older members of the family or by the media. Although we all learned at school about the Black Plague which in the mid- $14^{\text {th }}$ century depopulated Europe, only a few of us know that the so-called "Spanish flu" that killed tens of millions of people all over the world in 1918-1919 (Encyklopedia PWN). Little is the awareness that nowadays the risk of epidemics remains real and limiting preventive vaccination exceedingly increases the risk of their occurrence.

The obligation of preventive vaccination must not be viewed merely as the legal enforcement of safeguarding one's own security and health. First and foremost, it must be interpreted as an obligation serving public security. However, what becomes necessary for this purpose is information, social dialogue and appropriate communication between medical circles and the public. 
It seems worth noticing that the concept of a democratic state assumes, among other things, that it is a state respecting the rule of law and human rights. The right to freedom and self-determination undoubtedly constitute human rights, which also include the right to live and the right to health. In the context of epidemiological risk, in the case of non-acceptance of obligatory vaccination, these rights become contradictory. The philosophy of the state in its very essence assumes that public welfare may prevail over individual freedom, which underlies the concept of public interest. Therefore, the necessity to restrict some rights and implement certain obligations is not contradictory to the foundations of a democratic state. It is essential, however, that the obligation (in this case - the obligation of vaccination as a means of exercising public interest) should be exercised within the frame of rule of law. When it is necessary to restrict individual liberties, as is the case when the obligation of vaccination excludes the possibility to express consent for vaccination, then it is particularly important that such restrictions have their roots in unambiguous legal regulations - clear and not leaving room for interpretative freedom.

\section{The right to express consent for a medical intervention as the right to liberty and self-determination in a democratic state}

In a democratic state, liberty is particularly protected including the freedom to private life and independence in making choices. Freedom is also the basic principle of the contemporary human rights doctrine (Supreme Court, 27.10.2005). One aspect of freedom is the right to self-determination (Kołodziej, 2002, p. 75), guaranteed in Art. 41 Par. 1 of the Constitution, pursuant to which: "personal immunity and liberty are to be ensured to every individual. Deprivation or restriction of personal liberty may take place only in accordance with the principles and in the manner laid down in the Act". The freedom of an individual to make choices, particularly in relation to medical treatment are signs of autonomy. The institution of consent for carrying out medical intervention, one of the fundamental and essential prerequisites of the lawfulness of medical activities (Supreme Court, 27.10.2005), overruling the unlawfulness of a doctor's activity (Nesterowicz, 2012 , p. 179), represents realization of the right to self-determination.

Nowadays, a tendency might be observed to broaden the autonomy of an individual in the sphere of decisions related to their health (Safjan, 1991, p. 10). Both in the doctrine and in judicature, it is emphasized that a patient 
must not be treated as an object of someone else's decisions and deprived of discretion as regards their health (Supreme Court, 1.04.2004; Supreme Court, 11.04.2006; Supreme Court, 8.07.2010). The patient's empowerment manifests itself in the obligation of proper cooperation of the doctor and the patient (Liszewska, 1999, p. 87), which results in creating a relation between these two entities based on partnership. It seems important to notice that presently a rudimentary standard of partner relation between the doctor and the patient is the requirement of the patient's consent for the specified medical intervention that is to be undertaken. The patient is an equal subject of this relation and their consent becomes a crucial element "anchoring" doctors' actions both axiologically and legally. Moreover, the patient's will determines the scope as well as the conditions of medical intervention (Niemczyk \& Łazarska \& Niemczyk, 2007, p. 50). The consent must be expressed by the patient knowingly to be effective (Nesterowicz, 1999, p. 70; Świczewska, 2006, p. 131; Niemczyk \& Łazarska, 2005 p. 57; Balicki, 1998, p. 81).

In order to enable the patient to give an informed consent, it is necessary to apprise them to such extent that will allow them to acquaint themselves with the circumstances and analyse the risks and benefits connected with undertaking the specific medical intervention. It should be pointed out that the lack of adequate information precludes the awareness and consequently results in absolute invalidity of the consent (Świderska, 2004, p. 597). As the Supreme Court rightly commented in its ruling of 17 December 2004, "the mere consent of the patient to carry out the intervention, obtained in the situation of the lack of informing them beforehand in an accessible way, must not be considered as a consent in a juridical meaning of this word" (Supreme Court, 17.12.2004). The Supreme Court in its judgment of 28 September 1999 held that the doctor should inform the patient about all consequences of the treatment which "are normally its effect, i.e. desired - in view of its purpose - effects of the treatment, as well as other effects (so called adverse effects)". In the Court's opinion, the information should in particular comprise these foreseeable possible effects of the treatment, especially if they are consequences consisting in considerable and significant damage to health, which in fact - as adverse effects - occur infrequently or sporadically but cannot be excluded. The information ought to specify the probability of their occurrence. In this case, however, it can hardly be required that the information should enumerate all possible symptoms of the effects of the treatment and comprise their description. It will suffice to broadly specify the kind of possible effects of the treatment and indicate whether they may endanger patient's life or what might 
Health security in a democratic state: child vaccination - legal obligation...

be their impact on the correct functioning of patient's organism (Supreme Court, 28.09.1999).

Thus, consent to undergo medical treatment plays a vitally important role in performing medical intervention. Not only does it determine whether undertaking medical activities by medical personnel is lawful but also it decides about their scope and kind. Both in doctrine and in judicial decisions there prevails a view that each activity of a doctor may be performed, except for situations stipulated by legal provisions, exclusively with the patient's consent (Nesterowicz, 2013, p. 149. Otherwise such activity is unlawful (Nesterowicz, 2012, p. 114; Migalska, 2010, p. 141; The Court of Appeal in Warsaw, 31.03.2006), even in the situation when it was performed in therapeutic purpose towards the patient and in conformity with the principles of good practice in medicine. As a consequence of emphasizing the patient's consent for the medical activities performed towards them, the following principles are exercised: the protection of autonomy in deciding about oneself, the protection of privacy and the principle of respect of physical integrity (Safjan, 1998, p. 34), which serves the protection of the values underlying the functioning of a democratic state of law.

\section{The civil right to health in a democratic state. The obligation of preventive vaccination.}

The right to health is just as important as the right to liberty. It should be stressed that life is the supreme value. Hence, the right to live and the right to health must be particularly protected in a democratic state. Legal protection of life is guaranteed by the Constitution Art. 38, which provides directly that "the Republic of Poland ensures legal protection of life to every person", while legal protection of health in Art. 68 Par. 1 of the Constitution, provides that "every person has the right to protection of their health". Implementing obligatory vaccination indicates the realization of state policy as regards the protection of Polish citizens' health, as well as the health of other persons staying on the territory of the Republic of Poland, against certain contagious diseases. The obligation to undergo preventive vaccination arises under the Act of 5 December 2008 on preventing and fighting infections and contagious diseases in humans (hereinafter, the Act) where, in Art. 5 Par. 1 item 1 letter b, it is set forth directly that persons staying on the territory of the Republic of Poland are obliged to undergo preventive vaccination in accordance with the principles stipulated by the Act. An exception is made for persons staying on the territory of the Republic of 
Poland for less than three months, who, subject to the provisions of Art. 17 Par. 1a of the Act, are exempted from the obligation of undergoing obligatory preventive vaccination, save in the case of post-exposure treatment.

The obligation of preventive vaccination refers to contagious diseases listed in the regulation of the Minister of Health of 18 August 2011 concerning obligatory preventive vaccination issued on the basis of delegated legislation included in Art. 17 Par. 10 of the Act. Pursuant to $\S 2$ of the aforementioned regulation these include contagious diseases.

The said regulation, except for the list of obligatory preventive vaccinations, specifies the people or groups of people who are under obligation of undergoing preventive vaccination against contagious diseases, as well as age and other circumstances which are preconditions to imposing the obligation. The regulation indicates then, who and in what circumstances and in which period of life is subject to preventive vaccination against a specific disease taking into consideration epidemiological data regarding the number of incidences of diseases, current medical knowledge and the recommendations of WHO. Obligatory preventive vaccinations are performed in compliance with the Preventive Vaccination Plan for the given year that is declared by the Chief Sanitary Inspector in the form of an official public announcement ( $\S 5$ of the regulation) pursuant to Art. 17 Par. 1 of the Act. The Preventive Vaccination Plan for the given year includes not only detailed instructions regarding the application of each vaccine resulting from the current epidemiological situation and legal provisions but also recommendations. The Plan precisely indicates against which contagious diseases and in which month or year of life a child should by vaccinated. As emphasized in judicial decisions, the Plan issued in the form of an Announcement by the Chief Sanitary Inspector includes specialist information from the medical area regarding technical issues of exercising the duty of vaccination (the Administrative Court in Warsaw, 10.02.2017; the Supreme Administrative Court, 12.06.2014; the Provincial Administrative Court in Cracow, 25.10.2012). This method of deciding on the types of vaccinations to be administered, as observed by the Provincial Administrative Court in Cracow, guarantees that advances in the field of medicine and epidemiologic situation are appropriately used.

To recapitulate on the above discussion, it needs to be unambiguously established that the obligation of preventive vaccinations, involving minors, arises from Art. 5 Par. 1 letter b in connection with Art. 17 of the Act on preventing and fighting infections and contagious diseases. It is a legal obligation. As rightly argued in judicature (the Supreme Court, 8.01.2016; the Provincial Administrative Court in Bialystok, 1.02.2011; the Provincial 
Administrative Court in Bydgoszcz, 4.11.2015), the obligation to subject a child to preventive vaccination results directly from the operation of law, therefore there is no ground for issuing administrative decisions by sanitary inspection bodies in this respect. The obligation of subjecting a child to preventive vaccination, which results from legal regulations, is directly enforceable. Thereby, failure to comply with the obligation triggers the duty to initiate execution proceedings. It is the parents who are responsible for vaccinating the child. As explicitly follows from Art. 5 Par. 2 of the Act, in the case of a person not fully capable to perform acts in law the responsibility for complying with the obligation of preventive vaccination "lies on the person who exercises parental care over a person under age or a vulnerable person or a customary carer in the sense of Art. 3 Par. 3 point 1 of the Act of 8 November 2008 concerning patient's rights and Patients' [Rights] Ombudsman. Failing to comply with this obligation by parents brings up the obligation to initiate execution proceedings, whose intended effect is subjecting a child to preventive vaccination" (Supreme Court, 8.01.2016).

\section{Legal obligation of the parents to subject a child to vaccination}

Due to the fact that subjecting a child to preventive vaccination specified in the regulation of The Minister of Health of 18 August 2011 concerning obligatory preventive vaccination is a legal obligation, parental consent for vaccinating a child is not required. Moreover, parents may not lodge a legally effective objection. Subjecting a child to vaccination is complying with a statutory obligation. As rightly argued in judicature (the Provincial Administrative Court in Warsaw, 21.03.2019; the Provincial Administrative Court in Bialystok, 16.04.2013; the Provincial Administrative Court in Warsaw, 10.02.2017), the statutory obligation of preventive vaccination entails the inadmissibility of exercising the patient's right to refuse subjecting to medical treatment invoking Art. 16 of the Act of 6 November 2008 on patient's rights and Patients' Rights Ombudsman (hereinafter, PPRzPP Act). Pursuant to the aforementioned provision, the patient is entitled to express consent for medical treatment or refuse to give such consent. However, it seems important to take a closer look at the content of Art. 15 of the PPRzPP Act which stipulates as follows: "the provisions of this chapter are applied to expressing consent for medical treatment or refusing to give such consent, unless otherwise provided for in separate Acts". This means then, that provisions concerning patient consent, 
including Art. 16 of the PPRzPP Act, are applicable only when there are no other provisions set forth in other separate Acts, which provide otherwise. As observed in judicial decisions (the Provincial Administrative Court in Warsaw, 21.03.2019; the Provincial Administrative Court in Bialystok, 16.04.2013; the Provincial Administrative Court in Warsaw, 10.02.2017), such a separate Act is, among others, the Act of 5 December 2008 concerning preventing and fighting infections and contagious disease in humans, which in Art. 5 Par. 1 point 1 letter b, imposes the obligation on persons staying within the territory of the Republic of Poland to subject to undergoing preventive vaccination. Therefore, said Act does not provide for the patient's right to refuse giving their consent - it specifically denies that right. Bearing in mind the above argumentation, it must be highlighted that parents cannot refuse to subject their child to obligatory preventive treatment and their consent is not required by law. A similar position is adopted by some representatives of the doctrine, among others by M. Boratyńska, who thinks that "in the case of obligatory vaccination of a minor the statutory representative's consent is not required, since it is about complying with an obligation" (Boratyńska, 2013, p. 74). This view is shared by J. Kosonoga-Zygmunt (Kosonoga-Zygmunt, 2016, p. 175). As J. Haberko also notices "performing the obligatory preventive vaccination remains beyond the person's will" (Haberko, 2006, p. 24). However, not all representatives of the doctrine think along the same lines. According to A. Augustynowicz and I. Wrześniewska-Wal, "the fact that there exists an obligation of subjecting to certain preventive vaccinations does not authorize to perform such action without (...) the consent or against the consent of the person" (Augustynowicz \& Wrześniewska-Wal, 2013, p. 123). Similarly, I. Jaworska stands on the position that "provisions of the Act concerning preventing and fighting infections and contagious diseases in humans shall not exclude the provisions concerning the obligation of the doctor to obtain the minor's parents' consent. Thereby, there is an obligation which pertains subjecting a child to (...) vaccination" (Jaworska, 2017, p. 64). In N. Karczewska-Kamińska's opinion, the doctor cannot perform vaccination without consent while in this case the patient (parent) may not refuse giving his or her consent (N. Karczewska-Kamińska, 2018, p. 206). A comparable viewpoint is represented by $\mathrm{R}$. Kubiak, according to whom "a doctor may not perform vaccination of a child against the will of its parents $(\mathrm{Ku}-$ biak, 2015, p. 55).

It seems important to notice that the procedure of submitting oneself to vaccination is a preventive measure, which inextricably comprises two activities: 
1) medical examination preceding the qualification for vaccination

2) application of the vaccine orally or by injection.

Thorough analysis of the provisions of the Act leads to this conclusion. Subject to Art. 17 Par. 2 of the Act, performing the vaccination is preceded by a medical qualifying examination to exclude contraindications against vaccination while, pursuant to Art. 17 Par. 3 of the Act, if, between the medical qualifying examination being conducted and actual vaccination a period of 24 hours has elapsed, then the vaccine cannot be administered. One must acquiesce then with the Provincial Administrative Court in Warsaw (8.09.2017), that irrespective of the rather awkward wording of the regulations, which might be understood in the way that performing obligatory vaccination boils down to the mere act of applying vaccine, it should be admitted that the medical qualifying examination, mentioned in Art. 17 Par. 2 of the Act, is an integral part of the obligatory preventive vaccination procedure insofar that it determines its admissibility. The examination is aimed at deciding whether the person's state of health allows for vaccinating them. Therefore, the examination is inseparably linked with the activity of introducing vaccine into the organism. The above argumentation means that the legal obligation of subjecting a child to vaccination comprises also the obligation of undergoing a qualifying examination preceding the procedure. Hence, both for the vaccination itself and the preceding qualifying examination the parents' consent is not required and likewise, in both cases the parents cannot lodge a legally effective objection. Such a standpoint is also represented in case law (the Provincial Administrative Court in Warsaw, 10.02.2017; the Provincial Administrative Court in Bialystok, 16.04.2013; the Provincial Administrative Court in Bydgoszcz, 4.11.2015; the Provincial Administrative Court in Warsaw, 8.09.2017), wherein it is directly indicated that enforcing the obligation of vaccination covers also enforcing the obligation of the child undergoing a medical qualifying examination, which is inseparably linked with the vaccination. This viewpoint is shared among others by J. Kosonoga-Zygmunt, who believes that "a qualifying examination is a precondition for performing vaccination and thus it must be considered obligatory on par with the vaccination itself - and since it is obligatory then it does not require the patient's or their statutory representative's consent" (Kosonoga-Zygmunt, 2016, p. 176), and also by J. Haberko (Haberko, 2006, p. 24).

At this point, however, it needs to be noted that these provisions, owing to their unclear and vague wording, are differently understood by some parents, who are addressees of the legal standard incorporated therein. They 


\section{Dorota Huzarska-Ryzenko, Joanna Huzarska, Bartosz Pędziński}

point to the fact that the "qualifying examination is a prerequisite that determines triggering the obligation to submit oneself to preventive vaccination" (the Provincial Administrative Court in Warsaw, 10.02.2017). Concurrently, they contest maturity of the obligation to subject to obligatory vaccination, pointing to the lack of qualifying examination and the right to refuse undergoing this examination under Art. 16 of the Act on patient's rights and Patients' Rights Ombudsman (the Provincial Administrative Court in Warsaw, 10.02.2017). A similar position is also adopted by some representatives of science. As N. Karczewska-Kamińska puts it, "obligatory preventive vaccination must be preceded by a medical qualifying examination which cannot be carried out without consent (Karczewska-Kamińska, 2018, p. 205). According to I. Jaworska, "the provisions of the Act concerning preventing and fighting infections and contagious diseases in humans shall not exclude the provisions concerning the obligation of the doctor to obtain the minor's parents' consent. Thereby, there exists such obligation which pertains subjecting a child to the examination as well as vaccination" (Jaworska, 2017, p. 64).

Given the above, one must find that the language used in the Act is not sufficiently clear and neither is it unambiguous. Undoubtedly, it would be advisable to regulate this issue unequivocally, so as to be comprehensible to those applying the aforementioned provisions, persons obliged to receive preventive vaccine and, in the case of persons under age, their statutory representatives, i.e. parents. It would be expedient to reword the provisions of the Act or supplement it with a provision which would explicitly indicate that the examination qualifying for vaccination is an integral part of the procedure and for this reason subjecting to this examination constitutes a legal obligation, or with a provision from which the obligation to undergo such examination would directly follow. At this point it must be emphasized again that the language of legal provisions ought to be clear and raise no interpretative doubts whatsoever, particularly in the case of provisions which impose a legal obligation and thus restrict the right to freedom and self-determination.

The regulations concerning the maturity of the obligation of vaccinating a child, owing to the imprecise nature of their wording, are not clear to parents i.e. the persons obliged to comply with the obligation. As an example, pursuant to the content of $\S 3$ clause 7 of the regulation the obligation of undergoing obligatory preventive vaccination against measles concerns children and adolescents ranging from 13 months to 19 years of age. From the wording, some parents conclude that the obligation to vaccinate their child only becomes enforceable when the child turns 20 (the Provincial 
Administrative Court in Bydgoszcz, 4.11.2015). Such interpretation of the aforementioned provisions cannot be conformed with. It needs to be emphasized that under $\S 5$ of the regulation of the Minister of Health of 18 August 2011 concerning obligatory preventive vaccination, vaccination is carried out in compliance with the Preventive Vaccination Plan for the given year. As previously mentioned herein, the Preventive Vaccination Plans for each year specify precisely against which contagious diseases and in which month and year of life a child should be vaccinated. Thus, it seems sensible to admit that diversification of the lower and upper limit of the period falling within the obligation of preventive vaccination made in $\S 3$ of the regulation determines the time of commencement and expiry of the obligation to subject to vaccination, but not the period of enforceability of the obligation, which is emphasized in case law (the Provincial Administrative Court in Bialystok, 16.04.2013; the Provincial Administrative Court in Bydgoszcz, 4.11.2015). Meanwhile, it is highlighted that if, in enforcing the obligation (imposed on complainant) to subject a child to vaccination, the authorities had to wait until that child turns 20 years of age to proceed, then the goal of preventing the situations listed in Art. 33 of the Act would not be achieved; and as appears from life experience and general knowledge, such factors as the number of doses and periods in which the subsequent doses of vaccine must be given to children are conditioned by medicine (immunology) (the Provincial Administrative Court in Bydgoszcz, 4.11.2015). And here, it must once again be emphasized that the legal provisions concerning enforceability of vaccination need to be crystal clear and readily understandable, particularly to the parents who are the ones under obligation to subject their child to vaccination in due time.

As before mentioned, subjecting a child to preventive vaccination is a legal obligation which shall be complied with by the child's parents. Vaccination may be postponed by a doctor until such time as medical contraindications (where found to be present) cease to exist. Under Art. 17 Par. 5 of the Act, in the case where the medical qualifying examination gives grounds for long-term postponement of the vaccination, the doctor refers the person under obligation to a specialist for consultation. Pursuant to $\S 8$ Par. 1 of the regulation, the specialist who performs the consultation must document the outcome, having regard to the time of contraindications for vaccination, the kinds of contraindicated vaccines or individual plan of vaccination listing the kinds of vaccines applied and the date of the next consultation. Thus, as rightly argued in case law, it is a doctor who, after thorough examination of the child's current state of health and gathering all relevant information required during an interview with the parents, decides 
on each occasion upon carrying out preventive vaccination and qualifying a child to receive vaccination - not a parent, who having regard to their beliefs objects to performing preventive vaccination at the periods substantiated by medicine and epidemiology (the Provincial Administrative Court in Warsaw, 10.02.2017; The Provincial Administrative Court in Warsaw, 21.03.2019). Once again, it must be stressed that the parents' obligation to submit their child to obligatory preventive vaccination is a legal obligation, from which only specific medical contraindications against vaccination may exempt them (Supreme Court, 8.01.2016).

However, it should be mentioned here that pursuant to Art. 31 of the Act concerning patient's rights and the Patients' Rights Ombudsman, parents are entitled to object against the opinion of the doctor deciding upon their child's state of health, if they are not in agreement with the opinion and believe that contraindications exist to make vaccination inadvisable. The objection must be filed with the Medical Board acting for the Patients' Rights Ombudsman, through the Patients' Rights Ombudsman, within 30 days from the date on which the opinion on the child's state of health was issued.

The obligation of subjecting a minor to preventive vaccination was secured by the possibility of initiating execution proceeding, the purported outcome of which, as pointed out by the Supreme Court (8.01.2016), is subjecting a child to preventive vaccination. The body entitled to initiate execution proceedings is the voivode (regional administrative office). Failure to subject to obligatory vaccination, irrespective of applying the means of administrative execution, creates penal-administrative liability provided for under Art. $115 \S 1$ of the Code of Petty Offences. The same liability is imposed on any person who, exercising care over a minor or vulnerable person and despite applying administrative execution measures, fails to subject the minor or vulnerable person in their care to preventive vaccination (Art. $115 \S 2$ of the Code of Petty Offences) (Supreme Court, 8.01.2016). Pursuant to the aforementioned provision, a child's parents may be imposed with a fine of 1500 PLN.

\section{The obligation of preventive vaccination versus the restriction of civil rights and liberties}

The obligation to undergo preventive vaccination, although in principle accepted by parents, but not by all, results in the initiation of administrative proceedings against those who fail to subject their children to the proce- 
dure. Parents who fall into this category generally argue that they alone should have the right to decide about their child, including the decision on whether or not to undergo vaccination. However, the provisions of the Act unequivocally bind parents to subject a child to preventive vaccination, imposing a legal obligation and thereby restricting the right to freedom and parental determination in this respect.

Here, it needs to be reminded, and emphasized, that introducing obligatory preventive vaccination is based on the provisions of the Constitution of the Republic of Poland, in particular Art. 31 Par. 3. In the context of this provision, certain limits might be set on the exercise of constitutional freedoms and rights when, among other things, this is seen as being necessary in a democratic state to safeguard public health or to protect other persons' rights. The obligation of vaccination is directly connected with preventing the spread of contagious disease among the population and persons staying on the territory of the Republic of Poland. Prevention of epidemic diseases is a constitutional obligation of public authorities (Art. 68 Par. 4 of the Constitution).

As stated by the National Consultant for Public Health, "vaccinations are one of the most powerful tools possessed by public health. They are the most effective weapon in the battle against dangerous, often lethal, infectious illnesses jeopardizing health and life. They are an effective (...) method of preventing the spread of infectious illnesses, not only in the sense of individual prevention but also shaping the immunity of the whole population (mass prevention)". At the same time, he emphasized the fact that "only mass preventive vaccination against certain contagious diseases guarantees a sufficiently high percentage of persons immune against these diseases and effectively decreases the risk of epidemic spread of these diseases in the population". The National Consultant for Public Health also noted that "a refusal to vaccinate a child is a decision affecting not only this child's health, but also the immunity of the whole population. The decline in vaccination coverage level below $90 \%$ will result in recurrence of epidemics of illnesses that never or seldom occur in Poland" (https://gis.gov.pl/zdrowie/ stanowisko-krajowego-konsultanta-w-dziedzinie-zdrowia-publicznego-wsobowiazku-szczepien/).

As I. Jaworska rightly notices "the obligation of subjecting oneself to vaccination constitutes a restriction of civil rights and liberties. Above all it invades the child's, or actually its parents', personal freedom" (Jaworska, 2017, p. 60). Conversely, the consequence of not subjecting to vaccination a child who will later come down with an infectious disease might well prove disastrous for other persons. 


\section{Conclusions}

It must be emphasized that nothing but full realization of vaccination against contagious diseases guarantees health security to the whole of society, and that such diseases constitute a serious threat to the health and life of every man, woman and child. Therefore, it appears that the will of an individual as to whether or not to undergo preventive vaccination should be of lower priority. Taking the above into consideration, one must accept that in a democratic state the protection of public health against epidemic hazards justifies implementing legal solutions that restrict an individual's freedom to self-determination, thus limiting the right of patients or their statutory representatives to grant or refuse consent for medical intervention in the form of preventive vaccination - the purpose of this legal solution being to prioritize state health security for the better good of all citizens.

Parents must not refuse to subject a child to preventive vaccination and their consent in this regard is not required by law, both in terms of the medical qualifying examination to exclude contraindications to performing vaccination and the vaccination itself. It is a legal obligation from which exemption is only possible on grounds of certain medical conditions that would render vaccination inadvisable.

The provisions of law regarding obligatory preventive vaccination in Poland, in particular its enforceability, have not been formulated in a way that is fully comprehensible to the parents who are obliged to comply with them. The language of the legal provisions should be clear and unambiguous. After all, these are regulations that impose legal obligation, thus restricting the right to freedom and self-determination and failure to comply with them results in the instigation of administrative proceedings and criminal liability.

In a democratic state, the introduction of laws imposing compulsory preventive vaccination should be complemented by activities aimed at alleviating social concerns. In particular, a nationwide public information campaign should be used to convince parents that the obligation does not represent an unjustified infringement of their rights and freedoms - it aims exclusively at the protection of public health and the health of vaccinated children. Continuous social dialogue should ensure that the importance of universal vaccination for society is widely understood. For this purpose good communication between the medical community and the general public is of critical importance. 
Health security in a democratic state: child vaccination - legal obligation...

\section{R E F E R E N C E S}

Augustynowicz, A. \& Wrześniewska-Wal, I. (2013). Aspekty prawne obowiązkowych szczepień ochronnych u dzieci. Pediatria Polska, (88) 1, 120-126.

Balicki, M. (1998). Prawa pacjenta - wybrane zagadnienia. Szkoła Praw Człowie$k a, 5$.

Boratyńska, M. (2013). Szczepienia ochronne małoletnich a wykonywanie władzy rodzicielskiej. Uwagi na tle wyroku NSA. Prawo i Medycyna, 3-4, 68-88.

Dziennik.pl, Likwidacja obowiazku szczepień. Burzliwa debata w Sejmie. Retrieved May 30, 2019, from https://zdrowie.dziennik.pl/aktualnosci/artykuly/5824 50,antyszczepionkowcy-likwidacja-obowiazku-szczepien-debata-sejm.html

Encyklopedia PWN, Zarazy XX wieku. Retrieved May 30, 2019, from https://ency klopedia.pwn.pl/materialy-dodatkowe/haslo/Zarazy-XX-wieku;448856.html

Główny Inspektorat Sanitarny, Stanowisko Krajowego Konsultanta w dziedzinie Zdrowia Publicznego ws. obowiazku szczepień. Retrieved May 30, 2019, from https://gis.gov.pl/zdrowie/stanowisko-krajowego-konsultanta-w-dziedziniezdrowia-publicznego-ws-obowiazku-szczepien/

Haberko, J. (2006). Analiza prawna i postulaty zmiany Formularzy świadomej zgody pacjentki na leczenie operacyjne. Prawo i Medycyna, 3.

Jaworska, I. (2007). Odmowa szczepienia dziecka i jej konsekwencje prawne. Przeglad Prawa Publicznego, 3, 60-72.

Karczewska-Kamińska, N. (2018). Przymus leczenia i inne interwencje medyczne bez zgody pacjenta, Warszawa.

Kołodziej, A. (2002). Stopień autonomii woli pacjenta na tle ustawy o zawodzie lekarza i ustawy o ochronie zdrowia psychicznego. Prawo i Medycyna, 11.

Kosonoga-Zygmunt, J. (2016). Glosa do wyroku Sądu Najwyższego z dnia 8 stycznia 2016 r., sygn.. V KK 306/15. Prokuratura i Prawo, 11, 170-181.

Kubiak, R. (2015). Konsekwencje prawne sprzeciwu rodziców poddania dziecka obowiązkowym szczepieniom ochronnym. Analiza przypadków $w$ pediatrii, 2 , $52-58$.

Liszewska, A. (1999). Problem zgody pacjenta jako dylemat aksjologiczny. Prawo i Medycyna, 1.

Migalska, M. (2010). Zgoda pacjenta za zabieg leczniczy. Roczniki Nauk Prawnych, $20(1), 141-154$.

Nesterowicz M. (2012). Prawo medyczne. Komentarze i glosy do orzeczeń sadowych. Warszawa.

Nesterowicz, M. (1999). Cywilnoprawne aspekty transplantacji komórek, tkanek i narządów. Prawo i Medycyna, 3.

Nesterowicz, M. (2013). Prawo medyczne, Toruń.

Niemczyk, S. \& Łazarska, A. (2005). Materialnoprawne elementy aktu zgody pacjenta w ujęciu prawnym i medycznym. Prawo $i$ Medycyna, 2. 
Niemczyk, S., Łazarska, A. \& Niemczyk, K. (2007). O granicach zgody pacjenta na czynność medyczną podwyższonego ryzyka. Prawo i Medycyna, 4.

Safjan, M. (1991). Współczesne tendencje i dylematy odpowiedzialności cywilnej lekarza. Przeglad Sadowy, 3.

Safjan, M. (1998). Prawo i medycyna. Ochrona praw jednostki a dylematy wspótczesnej medycyny. Warszawa.

Sejm RP, Interpelacja nr 7940. Retrieved May 30, 2019, from http://orka.sejm.gov. pl/sejm8.nsf/interpelacja.xsp?documentId=EDB52920D3A9C7C3C1258074 004FEA06\&view $=1$

Świczewska, A. (2006). Zgoda "poinformowana" (consentement eclaire) oraz współuczestniczenie w podejmowaniu decyzji o leczeniu (decision artagee) - uwagi na tle regulacji prawnych oraz orzecznictwa polskiego i francuskiego. Przeglad Prawniczy Uniwersytetu Warszawskiego, 1.

Świderska, M. (2005). Glosa do wyroku Sądu Najwyższego - Izba Cywilna z dnia 17 grudnia 2004 r. II CK 303/04. Orzecznictwo Sadów Polskich, 11.

\section{Legal acts}

The Constitution of the Republic of Poland of 2 April 1997 (Journal of Laws 1997 no. 78 , item 483 as amended).

The Act of 20 May 1971 the Code of Petty Offences i.e. Journal of Laws no. 2019 item 821).

The Act of 6 November 2008 concerning patient's rights and Patients' Ombudsman (i.e. Journal of Laws 2017 item 1318).

The Act of 5 December 2008 concerning preventing and fighting infections and contagious diseases in humans. (i.e. Journal of Laws 2016 item 1866 as amended).

The regulation of the Minister of Health of 18 August 2011 concerning obligatory preventive vaccination (Journal of Laws no. 2018 item 753).

\section{Judgments}

Judgment of the Provincial Administrative Court in Warsaw of September 2017 VII SA/Wa 2139/16. NSA database.

Judgment of the Provincial Administrative Court in Warsaw of February 2017 VII SA/Wa819/16. Lex no. 2252052.

Judgment of the Provincial Administrative Court in Cracow of 25 October 2012 III SA/Kr 1533/11 NSA database.

Judgment of the Provincial Administrative Court in Białystok of 1 February 2011 II SA/Bk 723/10. Lex no. 965291.

Judgment of the Provincial Administrative Court in Białystok z dnia 16 kwietnia 2013 r. II SA/Bk 18/13. Lex no. 1310128.

Judgment of the Provincial Administrative Court in Bydgoszcz of 4 November 2015 II SA/Bd 871/15. Lex no 1948739. 
Health security in a democratic state: child vaccination - legal obligation...

Judgment of the Provincial Administrative Court in Warsaw of 21 March 2019 VII SA/Wa 2206/18 NSA database.

Supreme Court Judgment of 28 September 1999 II CKN 511/98. Lex nr 453701.

Supreme Court Judgment of 1 April 2004 II CK 134/03. Lex no. 355344.

Supreme Court Judgment of 17 December 2004 II CK 303/04. OSP 2005/11/131.

Supreme Court Decision of 27 October 2005 III CK 155/05. OSNC 2006/7-8/137.

Judgment of the Court of Appeal in Warsaw of 31 March 2006 I ACa 973/05. OSA $2008 / 1 / 2$.

Supreme Court Judgment of 11 April 2006 I CSK 191/05. LexPolonica no. 406607.

Supreme Court Judgment of 8 July 2010 LexPolonica no. 2452362.

Supreme Administrative Court Judgment of 12 June 2014 II OSK 1312/13.

Supreme Court Judgment of 8 January 2016 V KK 306/15. Lex no. 1963649. 